\title{
A KURDISH GARSHUNI POEM BY DAVID OF BARAZNE (19TH CENTURY) ${ }^{1}$
}

\author{
MUSTAFA DEHQAN \\ INDEPENDENT SCHOLAR, IRAN
}

AND

\author{
Alessandro MengozZI \\ UNIVERSITY OF TURIN, ITALY
}

\begin{abstract}
This publication of a Kurdish lament by the Chaldean priest David of Barazne (d. 1880) is based on the autograph manuscript that contains his poems in Syriac, Neo-Aramaic and Kurdish. The poem is presented in the context of the traditional openness of the Church of the East towards multilingualism and the sociolinguistic profile of East Syrians living in Kurdistan. The sophisticated, yet inadequate, system of writing Kurdish phonemes in Syriac script combines Classical Syriac conventions with conventions and diacritics which are used
\end{abstract}

1 This paper is dedicated to the memory of Mirella Galletti, who devoted her life to the study of Kurdish history and culture. Mustafa Dehqan is the author of the section entitled Text and Translation and expresses his warm thanks to Newzad Hirori and Michael L. Chyet who improved the reading of the text. Alessandro Mengozzi prepared the text in Syriac script for the edition and is the author of the introduction and the sections entitled East-Syriac Garshuni and Kurdistani multilingualism, David of Barazne, and Kurdish in East-Syriac script. 
for other languages, especially Arabic and Neo-Aramaic. The text edition is accompanied by a transcription in modern Kurdish orthography and English translation.

Since the 19th century, Bible translations into varieties of Kurdish, often limited to single books, have been sponsored by western missionaries or Chaldean prelates and prepared or revised by Kurdish scholars. ${ }^{2}$ They were printed in various alphabets: Roman, Arabic and Armenian. Much less is known about Christian Kurdish texts preserved in manuscripts and, among them, about those written in Syriac script. Both West- and East-Syriac authors appear to have written in Kurdish Garshuni and the very few texts which are known or published may in fact bear witness to a wider phenomenon and a more consolidated and wide-spread literary tradition. To say the least, these texts confirm the cultural and pastoral appeal of Kurdish dialects for Syrian Orthodox and Chaldean clergymen.

Pennacchietti describes a grammar in Classical Syriac verses of the Kurdish dialect of the Badinān district (Zakho-Dehok-Amadiya in northern Iraq), the south-eastern fringe of the vast Kurmanji territory. The text was composed by the Chaldean monk Ablahad 'Odisho' of the Rabban Hormizd monastery near Alqosh and is preserved in a manuscript of the Iraqi Museum. ${ }^{3}$ Harrak gives a full description of the manuscript, that besides Ablahad's grammar in verse contains Kurdish sayings and proverbs, the Kurdish translation of a number of chapters of New Testament books and two hymns On Resurrection written in Kurdish by Father Ablahad in 1888.4

2 M. Dehqan, “A Kirmașanî Translation of the Gospel of John,” Journal of Eastern Christian Studies 61:1\&2 (2009), 208-9.

${ }^{3}$ F. A. Pennacchietti, "Un manoscritto curdo in karshuni da Aradin (Iraq)," Annali dell'Istituto Universitario Orientale di Napoli 36 (1976), 548-52.

${ }^{4}$ Ms. 18078 in A. Harrak, Catalogue of Syriac and Garshuni Manuscripts. Manuscripts Owned by the Iraqi Department of Antiquities and Heritage, CSCO 639, Subsidia 126 (Leuven: Peeters, 2011), 28-34. Harrak mentions other Kurdish translations of chapters of the Gospels and other Christian sources, made by a certain Yūsif of 'Aqrā in 1855. They are preserved in the manuscript collection of durekyața (Neo-Aramaic hymns) and mêmrè (a term generally used for poems and non-stanzaic hymns in the late EastSyriac tradition), listed as ms. 96 of the Diocese of 'Aqra in Y. Habbī, 
Kreyenbroek publishes a rather long poem composed in Kurdish, written in West Syriac script and attributed to Maphryono Basilius Simon of Tur 'Abdin (died 1740). The poem is called lawîj 'religious chant' and consists of 51 verses. Each verse begins with the vocative particle 10 'oh!' and consists of four lines. "No uniform pattern can be detected to suggest a metre based either on the length or number of syllables." Prosodic inconsistency, however, is compatible with a musical performance of the text. The four lines of each verse are generally linked by end-of-line rhyme. The poem addresses topics typical of Christian paraenetic discourses: the resurrection at the end of time, the final judgment and the necessity of repentance, death and the vanity of this world, glory of the saints in paradise, punishment of the sinner in hell. ${ }^{5}$

Some of these themes also occur in the Kurdish Garshuni poem that comes from the song book of the 19th-century Chaldean poet David of Barazne and will be published in the present paper. David's book will be presented in the framework of the literary effects of multilingualism, especially in poetry, among East-Syriac authors. A few remarks on the Garshuni transliteration system employed in the autograph manuscript will precede the text edition, a transcription according to modern Kurdish orthography, and an English translation.

\section{EAST-SYRIAC GARSHUNI AND KURDISTANI MULTILINGUALISM}

East-Syriac script has been used to write a variety of languages other than Classical Syriac. This is certainly due to the fact that the Syrian Churches are traditionally well-equipped to face multilingualism and multiculturalism, ${ }^{6}$ especially the Church of the East,

"Mahțūțāt abrašiyyat "Aqrā," in Fahāris al-mabstūtat al-suryāniyya fì l-'Irāq, (Baghdad: Al-Mağma' al- 'ilmī al- "irāqī, 1981), 70; presently unavailable.

${ }^{5}$ P. G. Kreyenbroek, "The Lawij of Mor Basilios Shim 'un: A Kurdish Christian Text in Syriac Script," Journal of Kurdish Studies 1 (1995), 2935. In G. A. Kiraz, Türrāṣ Mamllā. A Grammar of the Syriac Language, vol. 1 Orthography (Piscataway, NJ: Gorgias Press, 2012), 306-9, the paragraph on "Syro-Kurdish" is a detailed description of the transcription scheme used in the text published by Kreyenbroek.

${ }^{6}$ See the typological survey "Garšūnography I: Syriac as the Target Script” in G. A. Kiraz, Türrạs Mamllā, 291-322, and, on Turkish or Turkic and Persian Garshuni texts, in West- or East-Syriac script, in the Near 
thanks to its glorious tradition of pastoral and missionary work, carried on throughout the East: in Mesopotamia, the Arabian peninsula and Gulf region, Persia, Central Asia, India and China. Moreover, most of its learned congregations were and are bilingual. Especially during the Ottoman period, East Syrians developed their own Arabic Garshuni tradition, both in manuscripts and inscriptions, following the model of Garshuni proper, i.e. the Arabic often Middle Arabic - that Maronites have written in West-Syriac script, since the 13th century in marginal archival annotations and since the 15 th century in whole manuscripts. ${ }^{7}$

East and beyond: U. Marazzi, "Sull'importanza dei testi osmanli in caratteri siriaci," in Studia Turcologica memoriae Alexii Bombaci dicata, ed. A. Gallotta and U. Marazzi (Napoli: Istituto universitario orientale, 1982), 339-65; D. V. Proverbio, "Turco-Syriaca. Un caso estremo di sincretismo linguistico e religioso: i libri di Tommaso Șarrāf da Edessa (XVIII sec.) nella biblioteca portativa di Tommaso Caldeo da Alqôš," Miscellanea Bibliothecae Apostolicae Vaticanae 11 (2004), 583-635; H. Younansardaroud, "Die türkischen Texte aus dem Buch 'Manuel de Piété' von Paul Bedjan (1893)," in Studia Semitica et Semitohamitica. Festschrift für Rainer Voigt anläßlich seines 60. Geburtstages am 17. Januar 2004, Alter Orient und Altes Testament 317, ed. B. Burtes, J. Tropper and H. Younansardaroud (Münster: Ugarit, 2005), 489-525; P.G Borbone, "Syroturcica 1: The Önggüds and the Syriac Language," in Malphono w-Rabo d-Malphone. Studies in Honor of Sebastian P. Brock, Gorgias Eastern Christian Studies 3, ed. G. A. Kiraz (Piscataway, NJ: Gorgias, 2008), 1-18; Idem, "Syroturcica 2: The Priest Särgis in the White Pagoda," Monumenta Serica. Journal of Oriental Studies 56 (2008), 487503; Idem, "Syroturcica 3: Hulegu's rock-climbers. A short-lived Turkic word in 13th-14th century Syriac historical writing," in Studies in Turkic philology. Festschrift in honour of the 80th birthday of Professor Geng Shimin (Beijing: Minzu Dashue Chubanshe, 2009), 285-94; M. Maggi and P. Orsatti, "Two Syro-Persian Hymns for Palm Sunday and Maundy Thursday," in The Persian Language in History, ed. M. Maggi and P. Orsatti (Wiesbaden: Harrassowitz, 2011), 247-85; N. Sims-Williams, "Early New Persian in Syriac script: Two texts from Turfan," Bulletin of SOAS 74:3 (2011), 35374; all including bibliography.

7 A. Mengozzi, "The History of Garshuni as a Writing System: Evidence from the Rabbula Codex," in CAMSEMUD 2007. Proceedings of the 13th Italian Meeting of Afro-Asiatic Linguistics, held in Udine, May 21st-24th, 2007, ed. F. M. Fales and G. F. Grassi (Padova: S.A.R.G.O.N. Editrice e Libreria, 2010), 297-304; E. Braida, "Garshuni Manuscripts and Garshuni Notes in Syriac Manuscripts," Parole de l'Orient 37 (2012), 181-98. Kessel has recently pointed out that a late 13 th-century manuscript contains "one 
Even earlier, however, interesting literary specimens of the East-Syriac attitude towards multilingualism can be found in the "divan" attributed to the poet Khamis bar Qardahe, active in the last decades of the 13th century. In his Book hymns, songs and quatrains on religious and profane subjects are written in Classical Syriac, but most forms and motifs are of Persian origin. Among Khamis' Syriac poems, two Garshuni-like compositions have been preserved: a probably later hymn On Divine Economy, in which Syriac verses alternate with their Azeri Turkish translation - called 'Mongolian' in the rubrics - and three quatrains on love and wine that mix Syriac, Persian and a few Arabic words within the lines. ${ }^{8}$ Especially in the latter composition, which may very well be by Khamis, the poet deliberately shows his mastery of more than one language for poetic purposes and explicitly pays homage to the dominant model of Persian poetry. This kind of multi- and cross-linguistic virtuosity appears to be characteristic of the Islamic culture of that time $^{9}$ and therefore one of the distinctive features of the so-called Syriac Renaissance (10th-13th centuries), namely the openness of Syrian intellectuals of the Mongolian period to Islamic, i.e. AraboPersian, influence. ${ }^{10}$

of the earliest attestations of the Garšunī system of writing being used for literary texts, and so far the earliest dated one. It is especially important as a witness to the use of Garšunni in the Syrian Orthodox tradition, which is generally considered to be preceded by the Maronite one": G. Kessel, "The importance of the manuscript tradition of the 'Book of Grace' for the study of Garšūnī," Parole de l'Orient 37 (2012), 215.

8 A. Mengozzi, "Persische Lyrik in syrischem Gewand. Vierzeiler aus dem Buch des Khamis bar Qardahe (Ende 13. Jahrhundert)," in the proceedings of the Syrologentag (Göttingen, 16.-17. Dezember, 2011), forthcoming. Anton Pritula (Hermitage Museum, St Petersburg) is preparing a critical edition of the bilingual hymn On Divine Economy.

9 Bausani describes this phenomenon with the fascinating metaphor of musical variations on a theme: the theme is the common PersianIslamic culture and variation is given by the national languages, which are easily changed as if they were different styles of the same literature. A. Bausani, "Letteratura neopersiana," in Storia della letteratura persiana, ed. A. Pagliaro and A. Bausani (Milano: Nuova Accademia, 1960), 167.

10 G. B. Teule, "The Syriac Renaissance," in The Syriac Renaissance, Eastern Christian Studies 9, ed. G. B. Teule and C. Fotescu Tauwinkl (Leuven: Peeters, 2010), 23-8. 
Similarly, we find a virtuoso use of lexical choices in NeoAramaic poetry (late 15th century onwards), where multilingual hendiadys is a stylized reflection of the rich linguistic repertoire of the poets and their audiences: originally Aramaic words are flanked by synonyms derived from other languages, such as Classical Syriac, Arabic, Kurdish, Turkish or Persian. ${ }^{11}$ It is a rather common stylistic feature in Kurdish poetry too: see, e.g., p'êxamber... $\hat{u}$ enbîya 'prophet (Kurdish word)... and prophet (Arabic-derived word)' in 1. 11c of the poem by David of Barazne published below. Beyond Kurdistan, multilingual hendiadys is a common learned stylistic feature of Islamic literatures, where Arabic loans are flanked by their equivalents in languages such as Persian or Turkish. ${ }^{12}$

The tremendous impact of Kurdish on Neo-Aramaic at all levels - phonology, morphology, verbal system, vocabulary, phraseology, idiomatic expressions - has received scholarly attention and the conclusions of research on it do not need to be repeated here. ${ }^{13}$ An article by Chyet is particularly interesting, in that it is not confined to linguistic facts, but deals with literature, folklore and shared social and cultural institutions. ${ }^{14}$ Roving bards and storytellers are part of the traditional Kurdistani folklore that is shared by Muslims, Christians and Jews alike. In 1870, the famous Chaldean poet and bard Dawud Kora 'David the Blind' dictated Neo-

11 A. Mengozzi, A Story in a Truthful Language. Religious Poetry in Vernacular Syriac from (North Iraq, 17th century), CSCO 590, Scriptores Syri 231 (Leuven: Peeters, 2002), 100-2. On the same phenomenon in Jewish NeoAramaic literature, see Y. Sabar, A Jewish Neo-Aramaic Dictionary, Semitica Viva 28 (Wiesbaden: Harrassowitz, 2002), 55-6.

12 A. Bausani, "Le lingue islamiche. Interazioni e acculturazioni," in $\mathrm{Il}$ mondo islamico tra interazione e acculturazione, ed. A. Bausani and B. Scarcia Amoretti (Roma: Istituto di studi islamici, 1981), 9.

13 O. Kapeliuk, "Language Contact between Aramaic Dialects and Iranian," in The Semitic Languages. An International Handbook, HSK 36, ed S. Weninger (Berlin: de Gruyter, 2011), 738-47; Eadem, "A Contrastive Analysis of Tenses in Urmi Neo-Aramaic and in Kurdish," in Beiträge zur semitischen Dialek.tologie. Festschrift für Werner Arnold zum 60. Geburtstag, ed. R. Kuty, U. Seeger and Sh. Talay (Wiesbaden: Harrassowitz, 2013), 161-70.

14 M. L. Chyet, "Neo-Aramaic and Kurdish: An Interdisciplinary Consideration of their Influence on Each Other," Israel Oriental Studies 15 (1995), 219-49. 
Aramaic songs and Kurdish poems to Albert Socin. ${ }^{15}$ He was presumably able to perform in both languages. The tradition of Jewish story-tellers, often illiterate, and quite normally capable of performing on request in two or even three languages - Kurdish, NeoAramaic and Arabic - has continued up to more recent generations. ${ }^{16}$

The traditional openness of the Church of the East towards multilingualism and the rich sociolinguistic profile of East Syrians living in Kurdistan are the contexts in which we must place the linguistic choices of the 19th-century poet David of Barazne, who composed poems in Classical Syriac, Neo-Aramaic and Kurdish. Given the Aramaic and Kurdish bilingualism of many Christians in Kurdistan it is perhaps surprising that, as far as I know, he is one of the very few East-Syrians who committed his Kurdish verses to written form. ${ }^{17}$ Moreover, he is the only late East-Syriac and Neo-

${ }^{15}$ E. Prym and A. Socin, Kurdische Sammlungen. Erzäblungen und Lieder in den Dialekten des Țûr 'Abdîn und von Bobtan, a. Die Texte (St. Petersburg: Commissionaires de l'Académie Impériale des sciences, 1890), xvi.

${ }^{16}$ Y. Sabar, The Folk Literature of the Kurdistani Jews: An Anthology, Yale Judaica Series 23 (New Haven, CT: Yale University Press, 1982), xxxviixxxviii and M. L. Chyet, "Neo-Aramaic and Kurdish," 228-9.

${ }^{17}$ Harrak (Catalogue, 32-3) presents the two Kurdish hymns On Resurrection of the Ms. 18078 of the Iraqi Museum (f. 157v and 168v) as texts translated into Kurdish by the monk Ablahad of Alqosh. An anonymous Kurdish poem in East-Syriac script is preserved in three manuscripts copied for Eduard Sachau. E. Sachau, Verzeichnis der syrischen Handscbriften der Königlichen Bibliothek, zu Berlin, B. 1 (Berlin: Asher, 1899), 434-44. Ms. 133.6 (copied by J. Shamir in Mosul 1883) has the complete poem with interlinear Arabic translation; in ms. 134.1 (copied by the scribe Fransis in Telkepe 1883) the text is incomplete at the beginning; ms. 135.6 is a copy of 134 with Arabic translation, made by J. Shamir (Mosul 1883) at Sachau's request. The poem has romantic and adventurous contents and tells the story of a Kurd who fell in love with a certain Fatima, kidnapped her in Syria and took her to the Van region. Once, when he was trying to kill a mountain animal, possibly a wild goat, he shot but did not kill it. The wounded beast turned on the hunter and, as they fought, they both plunged into the abyss. In the same group of manuscripts, Jeremiah Shamir prepared an adaptation and partial translation of Faris El-Chidiac, $A$ Practical Grammar of the Arabic Language (London 1856) for Sachau, in the Neo-Aramaic dialect of Aynkawa and in the Kurdish dialect of Hakkari. English, Neo-Aramaic and Kurdish are arranged in three columns and both Neo-Aramaic and Kurdish are written in vocalized East-Syriac 
Aramaic poet of whom we have an autograph collection of poems and who often indulges in autobiographical details. These facts may very well be interconnected. He may have followed his poetic and linguistic inspiration in making a collection of poems, possibly intended for private use. On the other hand, late East-Syriac and Neo-Aramaic poems are usually preserved in miscellaneous manuscripts or anthologies that have religious content and liturgical function. Rather than Kurdish, authors were probably more inclined to use Classical Syriac, Arabic or, marginally, Neo-Aramaic in dealing with biblical, theological or hagiographical matters, and to avoid autobiography in textual supports for public celebrations. ${ }^{18}$

\section{DAVID OF BARAZNE ${ }^{19}$}

On the life of David of Barazne we have both direct and indirect sources of information. Direct information is provided in the colophons of the numerous manuscripts he copied as well as in his poems. David, son of Yohannan, son of Nisan, son of Gorgo, of the Qardahe family, was born around 1820 in the village called Barzāne, in the Zibār district. In 1841 and 1844 he lived in Ainkawa, first as a layman and later as a deacon. During a travelling seminar of a few months, he was trained as a priest while he accompanied the bishop 'Mar Yusep', who was probably Joseph Audo, bishop of Amadiya in 1833-47 and then elected as Patriarch Joseph VI. After a few days in Alqosh, he followed his bishop to Dehok, where he was ordained, and then went to the villages around

script: paradigms and texts in the ms. 133.1, word list in the ms. 136 (Mosul 1882-83). On these Kurdish Garshuni texts see also K. Fuad, Kurdische Handschriften, Verzeichnis der orientalischen Handschriften in Deutschland 30 (Wiesbaden: F. Steiner, 1970), 121-6.

18 For an overview on the linguistic policies of the East-Syriac churches in the 16th-19th centuries, see H. L. Murre-van den Berg, "Classical Syriac, Neo-Aramaic, and Arabic in the Church of the East and the Chaldean Church between 1500 and 1800," in Aramaic in its Historical and Linguistic Setting, Akademie der Wissenschaften und der Literatur, Mainz: Veröffentlichungen der Orientalischen Kommission 50, ed. H. Gzella and M. L. Folmer (Wiesbaden: Harrassowitz, 2008), 335-51.

19 J. M. Fiey, Assyrie Chrétienne (Beirut: Imprimerie catholique, 1965), vol. I, 169-71. 
Zakho with him. The place where he stayed longest seems to have been Bidaro, where he spent five months in 1846.

When the bishop sent him home, the priest David began his peregrinations and a life of hardship. As the poet sadly says of himself, he buried one of his family in each of the villages where he lived and worked. Misery and mourning did not prevent him from copying many manuscripts, a dozen of which have survived. ${ }^{20}$

The bishop was informed that Kurdish aghas of Zibār had attacked David's native village and sent the priest and his family to Khardes in the Sapsapa district. He remained there nine years, during which eight of his relatives died. He lost other dear ones in Herpa and witnessed a Kurdish raid on Șanaya d-Nahla. He left Zibār and the eAqra region and settled in Kanifalla, in the Gomel Valley (region of Amadiya), but his misfortune followed him. His wife died there and in 1865 he lost the only son who had survived, the beloved and learned Anton, who had helped him a great deal. The last manuscript David copied is a breviary dated 1871 .

In the biographical sketches that conclude his presentation of Sureth poetry, Father Jacques Rhéthoré describes David as a good priest and a talented poet. The French Dominican missionary must have known the poet personally and tells us about the end of his life. The famine that ravaged the Mosul region in 1880 did not spare poor David. He asked for help and protection from his friends in Mosul, but hunger and privation had severely weakened him and he died in the hospital of the Dominican mission, surrounded by the love and care of nuns and missionaries. According to Rhétoré, David's poems enjoyed a certain popularity and six of them were included in the Recueil de chants religieux en langue chaldéenne vulgaire, published in Mosul in 1886. However, Rhétoré observes that the manuscripts used for that edition were of rather poor quality. ${ }^{21}$

Given David's tormented existence, it is not surprising that his poems abound in themes such as sadness, the sinful life, death, the poet's miserable life, the death of his beloved son Anton, the vanity of this world and the coming of the Anti-Christ at the end of the world. These are in fact very common motifs in late East-Syriac

${ }^{20}$ D. Wilmshurst, The Ecclesiastical Organisation of the Church of the East, 1318-1913, CSCO 582, Subsidia 104 (Leuven: Peeters, 2000), 807.

21 B. Poizat, Jacques Rhétoré. La versification en soureth (araméen contemporain), CSCO 647, Subsidia 131 (Leuven: Peeters, 2013), 64-5. 
and Neo-Aramaic poetry. For the lament on the death of his son, David had a model in an analogous poem by Khamis bar Qardahe.22

The autograph collection of his poems was once kept in the library of the Dominican Monastery of Mar Yaqo, near Dehok, and is now part of the collection of Syriac manuscripts of the Dominicans of Mosul. ${ }^{23}$ According to the description annotated in pencil by Father Rhétoré on the last pages of the manuscript, it contains nineteen poems written in Classical Syriac, four poems in NeoAramaic and two poems in Kurdish: the Lament published here and a poem On the Love of this World and of Money, and the Imminent Coming of the Antichrist.

\section{KURDISH IN EAST SYRIAC SCRIPT}

It seems unlikely that David of Barazne had models for Kurdish Garshuni at his disposal. He probably invented the quite sophisticated system he used to transcribe Kurdish sounds (phonemes, but in certain cases allophones or phones too) in Syriac script, combining Classical Syriac conventions with special conventions and diacritics which were already in use for other phonological systems, namely Arabic, Neo-Aramaic and perhaps Persian.

Certain Syriac letters correspond to more than one Kurdish phoneme:

\begin{tabular}{|c|c|}
\hline \multirow{3}{*}{ gämal with a tilde below } & $/ c^{\prime} /$ unvoiced aspirated $\left[\mathrm{t} \mathrm{f}^{\mathrm{h}}\right]$ \\
\hline & /ç/ unvoiced \\
\hline & /c/ voiced $\left[\mathrm{d}_{3}\right]$ \\
\hline \multirow{2}{*}{ wān ${ }^{24}$} & $/ \mathrm{v} /$ \\
\hline & $/ \mathrm{w} /$ \\
\hline kāp & $/ \mathrm{k} /$ \\
\hline
\end{tabular}

22A. Mengozzi, "The Book of Khamis bar Qardahe: History of the Text, Genres and Research Perspectives," in Syriac Encounters, proceedings of the Sixth North American Syriac Symposium (Duke University, Durham, North Carolina, June 26-29, 2011), forthcoming.

${ }^{23}$ Ms. 82 in B. Sony, Le catalogue des manuscrits du couvent des Dominicains de Mossoul (Mosul, 1997).

${ }^{24}$ [v] supposedly existed as the fricative allophone of /b/ in Classical Syriac, but it does not occur in the Christian Neo-Aramaic dialects of northern Iraq, where $<\underline{b}>$ is usually pronounced $[\mathrm{w}]$. 


\begin{tabular}{|l|l|}
\hline \multirow{2}{*}{$p^{\bar{e}}$} & $/ \mathrm{k}^{\prime} /\left[\mathrm{k}^{\mathrm{h}}\right]$ \\
\hline \multirow{2}{*}{$r e \bar{s}$} & $/ \mathrm{p} /$ \\
\cline { 2 - 2 } & $/ \mathrm{p}^{\prime} /\left[\mathrm{p}^{\mathrm{h}}\right]$ \\
\hline \multirow{2}{*}{$\operatorname{taw} w$} & $/ \mathrm{r} /$ \\
\cline { 2 - 2 } & $/ \mathrm{r} /$ \\
\hline & $/ \mathrm{t} /$ \\
\cline { 2 - 2 } & $/ \mathrm{t}^{\prime} /\left[\mathrm{t}^{\mathrm{h}}\right]$ \\
\hline
\end{tabular}

There is no special sign for the series of Badināni aspirated consonants, written $\left\langle\mathrm{k}^{\prime}\right\rangle,\left\langle\mathrm{t}^{\prime}\right\rangle,\left\langle\mathrm{p}^{\prime}\right\rangle$ and $\left\langle\mathrm{c}^{\prime}\right\rangle$ in modern Kurmanji orthography, ${ }^{25}$ and for the trill $<\mathrm{r}>$. The gamal with a tilde $(\underset{\sim}{(})$ which is used for Arabic Garshuni $\check{g}$ and Neo-Aramaic $\check{g}$ or $\check{c}$ serves, as in Neo-Aramaic, for both the voiced and unvoiced palatal affricates of Kurdish. It is not clear whether the gamal with tilde in the word dejit $(17 \mathrm{a}, 18 \mathrm{~b})$ represents a dialectal affricate pronunciation dêcit or whether its use there is extended to the fricative $/ \mathrm{j} /$ ([3], here usually written $<\check{s}>$ with diacritics: $\dot{ث}$ ).

25 Given the phonemic status of aspiration in the Amadiya and Zakho dialects, MacKenzie proposes the aspirated voiceless plosives should be written $\left\langle\dot{p}, \dot{t}, k^{\prime}>\right.$ : D.N. MacKenzie, Kurdish Dialect Studies I, London Oriental Series vol. 9 (Oxford: Oxford University Press, 1961), 40. Thackstone leaves the aspirated consonants unmarked and suggests underlining the non-aspirated series, described as "accompanied by slight pharyngealization”: W. M. Thackston, Kurmanji Kurdish. A Reference Grammar with Selected Readings, 2006 [www.fas.harvard.edu/ iranian/ Kurmanji/kurmanji_1_grammar.pdf; last visit November 2013], 4. On the notation of these sounds in current Kurdish orthographies, Chyet observes that "the aspirated/non-aspirated consonantal pairs (p'-p/t'-t/k'-k/ç'-ç) are regularly distinguished by the Soviet scholars and in a few works by modern linguists. The Soviet scholars, many of whom also know Armenian, have no doubt been influenced by the existence of this feature in Armenian as well. This distinction is generally ignored in modern Kurdish publications... In the Arabic script, no way has been devised to distinguish these consonantal pairs. Nevertheless, for my informants from Iraqi Kurdistan - who are most comfortable using the Arabic script - the distinction is real, and has a phonemic importance": M.L. Chyet, "Kurmanji Kurdish Lexicography: A Survey and Discussion," web site of the Kurdish Academy of Language, 1997 [www.kurdishacademy.org/?q=fa/node/ 142; last visit November 2013]. Thus, the Garshuni system invented by David is in line with Iraqi Kurdish as written today in the Arabic script. 
A number of Syriac letters, especially in combination with diacritics, corresponds more precisely to specific Kurdish phonemes:

\begin{tabular}{|c|c|}
\hline 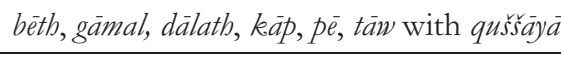 & $/ \mathrm{b} /, / \mathrm{g} /, / \mathrm{d} /, / \mathrm{k} /, / \mathrm{p} /, / \mathrm{t} /$ \\
\hline käp with rukkäkbā & $/ \mathrm{x} /$ \\
\hline$p e \bar{e}$ with a dot above & $/ \mathrm{f} /$ \\
\hline sin with three dots above & $/ \mathrm{j} /$ \\
\hline
\end{tabular}

Beghadkephath letters are often marked with quššàya in word-initial position, to avoid a reading of these consonants as fricatives. Käp with rukkäkha is used with the same value /x/ in Garshuni (for Arabic $\dot{\tau}$ ) and Neo-Aramaic, in the latter case even for etymological $b$ (e.g., khelmā 'dream').

Diacritics, such as a tilde and the dots above, are usually written in red ink. Pé with a thick (here colored red) dot above (') imitates the shape of Arabic $\omega$ and is in use for Neo-Aramaic words of Arabic origin and thus containing the sound /f/. ${ }^{26}$ It is unlikely that šin without dots in ji bîr (5b), dibêjî (9a) and nebêjin (13d) may reflect dialectal devoiced pronunciations, corresponding to standard Kurdish /ş/: şi bîr, dibêş̂̀ (?). More probably, the scribe did not go back to mark the diacritics in red ink. According to the available transcriptions and descriptions, / $\mathrm{f} /$ and $/ \mathrm{j} /$ are respectively written $\tilde{\Xi}$ and $\tilde{\Sigma}$ in the Kurdish Garshuni manuscript of the Iraqi Museum, 9 and $\dot{j}$ in the poem published by Kreyenbroek.

A number of consonants are used to write Kurdish phonemes or allophones which are not distinctively marked in standard Kurdish orthography. They represent Semitic phonemes and it is natural that the Syriac alphabet allows one either to mark their precise phonetic nature - pharyngeal or pharyngealized sounds - or to render them in historical spelling, since they are usually found in

26 A. Mengozzi, A Story in a Truthful Language, CSCO 590, 22-3. The post-vocalic allophone $[\mathrm{f}]$ or $\left[\mathrm{p}^{\mathrm{h}}\right]$ of late Aramaic /p/ usually does not occur in the Neo-Aramaic dialects of northern Iraq, where it invariably sounds [p] in all positions in words of Aramaic origin. This probably explains why in that region this special $p \bar{e}$ with a dot above was introduced for Neo-Aramaic Arabic-derived words containing an /f/. According to Classical Syriac orthography, a pē with a dot above (quššày $\bar{a})$ has the opposite value and indicates the occlusive allophone $[\mathrm{p}]$ or its geminated form [p:]. 
Kurdish words derived from Arabic. They are: hèth, used for un-

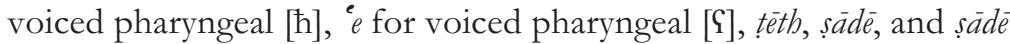
with a dot above, used for Arabic / $\mathrm{z} /$, in words such as wehîd (2a), emir (7b), betal (1c), qișe (1a), and rebb el'ezim (6d). A gämal with rukkäkba corresponds to the voiced allophone $[\gamma]$ of Kurdish / $\mathrm{x} /$ and the Arabic phoneme $/ \dot{\mathrm{g}} /:$ it is probably both a phonetic and etymological rendering of words derived from Arabic, such as mexmûn from magmūm (1b) and xerîb from garïb (7b). Standard Incîl and insanî are regularly spelled incîl (4c) and insanî (11b, 16a, 18a), which is possibly a phonetic spelling and indicates a pharyngeal realization of an initial hamza followed by short $i .{ }^{27}$

In a couple of words, consonants are repeated twice as if to indicate that they are geminated: lezet <lezzeta> (1c), kulin<kollin $>$ (3a), gelek < gellek> (3a and 3b), wê diêşin <wittêsin > ? (3a); dilê is written in three different ways: with double $l<$ dille $>$ (3c), with two lamads, the first of which is deleted with linea occultans, $\langle$ di(l)les $>$ (10d), and with just one $l$ in $\langle$ dile $\rangle$ (14c).

The system for writing vowel phonemes is as rich and inconsistent - in fact, inadequate - as the system used for consonants.

\begin{tabular}{|c|c|}
\hline zqäpāa $(+$ ālap $)$ & /a/ \\
\hline ₹qāpā & /e/ \\
\hline \multirow{2}{*}{ pthähạ } & /e/ \\
\hline & /i/ (one case, before $\underline{b}$ ) \\
\hline zlāmā prùqqà & /i/ \\
\hline - (elision for metrical purposes) & /i/ \\
\hline zlämā qašyyà (+ älap $)$ & $/ \mathrm{e} /$ \\
\hline \multirow{2}{*}{ bִbāṣa } & $/ \mathrm{e} /$ \\
\hline & $/ \hat{\imath} /$ \\
\hline \multirow{2}{*}{ rbaāșāa } & $/ \hat{\mathrm{u}} /$ \\
\hline & $/ \mathrm{u} /$ \\
\hline
\end{tabular}

${ }^{27}$ Incil is spelled with initial alap and yud in the Kurdish Garshuni ms. of the Iraqi Museum: إينجيل as Arabic (Harrak, Catalogue, 31). Interestingly, insän is written with initial gamal > jim (Harrak transliterates it as جنسان) in a marginal note of the same manuscript (ibidem, 28). These spelling variants may be mistakes or, less probably, reflect dialectal variation in the pronunciation of the initial syllable of these words. 


\begin{tabular}{|l|l|}
\hline \multirow{2}{*}{ rwähạā } & $\mathrm{/u} /$ \\
\cline { 2 - 2 } & $\mathrm{/o} /$ \\
\hline
\end{tabular}

The àlap which almost regularly follows a ₹qāpā or a ₹lämā qašy to write /a/ - as for Arabic long $\bar{a}-$ or / $\hat{\mathrm{e}} /$ is often marked with a linea occultans, that is the Classical Syriac conventional sign for consonants which are written as in historical spelling but not actually pronounced. It is used here as a rather pedantic way to indicate when älap is a mater lectionis. This alap with linea occultans is found elsewhere in late East-Syriac manuscripts for long vowels in foreign words, ${ }^{28}$ but it does not occur in the Kurdish Garshuni texts described by Pennacchietti, Kreyenbroek and Harrak. Zqäpā with älap - without linea occultans - occasionally occurs to mark a long $\bar{a}$ in Neo-Aramaic words of Arabic origin, as a Garshuni spelling: e.g., 7200内 'perfect'. 29

Inconsistencies in writing the Kurdish vowels with the Syriac punctuation system can probably be explained with reference to the phonologic status of vowels in Neo-Aramaic. In most Iraqi Neo-Aramaic dialects, vowel length is not phonemic, since short and long vowels are allophones and occur in complementary distribution: long vowels in open syllables and corresponding short vowels in closed syllables. This is probably why Kurdish /e/ is usually written with $p t h \bar{a} h \bar{a}$, but it is written with $2 q \bar{a} p \bar{a}$ in a couple of cases: e.g., gunehêd 3c or xerib 8a. The phonological status of /o/ and $/ \mathrm{u} /$ is uncertain in a number of Neo-Aramaic dialects, which probably explains the fact that Kurdish /u/ is written with rbagssa or rwāhā.

Short central /i/ ([I] or [i]) is either left unmarked or written with ₹lama $p$ šiqua . Once it is written $p t h a \bar{h} h \bar{a}$, when it immediately precedes a pharyngeal $b$ : bêsibeta (1b). When it is not written, probably it does not count as a syllable for metrical purposes. Its frequent elision - faithfully reflected in the script - is crucial in preserving the rigid isosyllabic structure of the verse lines. Each verse has four rhyming lines and most lines have ten vowels, i.e. ten syllables or ten syllabic feet. Nine- or eleven-syllable lines do occur. Rhyme pattern and syllabic structure are those of late Syriac and Neo-

${ }^{28}$ E.g., the court camp of the Mongols Ala Dagh, preceded by the

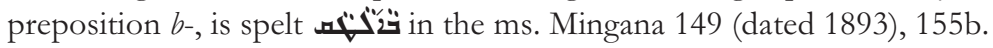

29 A. Mengozzi, A Story in a Truthful Language, CSCO 589, 318. 
Aramaic poetry, which is confirmed by the fact that the text can be sung to the tune of a Classical Syriac melody, as it says in the rubric. An imperfect rhyme occurs in $3 \mathrm{~d}(-\sin -\operatorname{sim})$, but the end rhymes that group the four lines of each verse are usually regular and are responsible for grammatically unacceptable vowel changes (poetic license). E.g., fera (9a) respects the rhyme of the verse, where one would expect the correct form fere, and rhyming iman $\hat{\imath}$ (16c) should in fact be imanê.

In Garshuni, typically Arabic orthographic conventions such as ta $\vec{a}$ marbutta, unassimilated lam of the definite article before solar consonants, älap for long $\bar{a}$, sometimes also alif wașla and even alif maqșüra (written with final $y u d$ ) are often adopted in Syriac script, which led Briquel-Chatonnet to speak of Garshuni as a Syriac writing system 'pensé en arabe'. ${ }^{30}$ On the contrary, David of Barazne appears to be making an attempt to write a dialectal variety of Kurdish that has no spelling conventions of its own. He feels free to follow typically Syriac orthographic conventions: the Kurdish conjunction $\hat{u}$ is regularly written as the non-syllabic proclitic equivalent $w$ - of Classical Syriac; 31 plural nouns are marked with sey$\bar{a} m \bar{e}$; the enclitic morpheme $-d$ in the Kurdish endings - $\hat{e} d$ is written as the proclitic Aramaic subordinator (-e $d-) ; 32 y u d$ with a superscript

${ }^{30}$ F. Briquel Chatonnet, "De l'intérêt de l'étude du garshouni et des manuscrits écrits selon ce système," in L'Orient chrétien dans l'empire musulman. Hommage an Professeur Gérard Troupeau, Studia arabica 3, ed. G. Gobillot and M.T. Urvoy (Paris: Éditions de Paris, 2005), 466. Kiraz classifies Arabic Garshuni - "Syro-Arabic" in his terminology - as a transliteration system, i.e. "a direct mapping of one writing system into another at the grapheme (not graph) level", and Kurdish Garshuni - "SyroKurdish" - as a transcription scheme, i.e. "the mapping of the sounds of one language into the graphemes of anther at the phoneme level" (G. A. Kiraz, Türrạṣ Mamllā, 292).

31 This spelling, which conforms with Classical Syriac orthography, possibly reflects a dialectal or an allegro pronunciation of the conjunction $\hat{u}$ as a short $u$ or as a consonantal $w$-. Accordingly, the conjunction would not seem to count as a syllable/foot for metrical purposes. In the poem published by Kreyenbroek, "The Lawij of Mor Basilios Shim "un", the Kurdish conjunction $\hat{u}$ is written as an underlined prefixed $w$ - (G. A. Kiraz, Türrāṣ Mamllā, 308).

32 The same phenomenon (proclitic $d$ - written according to Classical Syriac orthography for enclitic $-d$ as it is actually pronounced) is found in 
älap, which is a typical late East-Syriac ligature (2), conveniently marks the hiatus in çûina (19d).

\section{TEXT AND TRANSLATION}

\section{Transcription}

1. guhê xo biden li wê qiseta

qavya mexmûna û her bêsiheta

$\hat{\mathrm{u}}^{33}$ dunîya betala û nîya lezeta

mirof maya heyrî bi hemû babeta

2. mirina wehîda nexoşa û tehla

li bo day û baba qavya bêhala

heçî nedîtî nezanî çi hala

lomey min neken ya dost $\hat{u}$ hevala

3. birînêd min kulin gelek wê diêşin ${ }^{34}$
Dominicans of Mosul, ms. 82, pp. $143-5$

• •

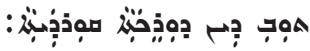

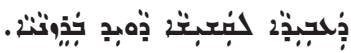

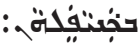

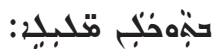

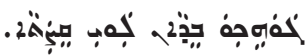

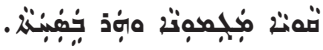

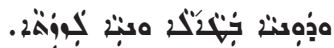

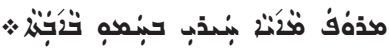

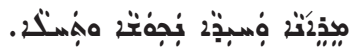

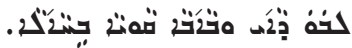

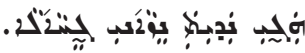

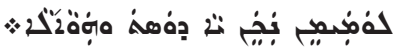

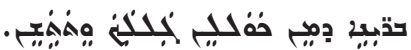

Neo-Aramaic writing systems that are based on Classical Syriac script and conventions, both in manuscripts and printed books.

${ }^{33}$ Here and elsewhere $\hat{u}$ is used at the beginning of the third line to emphasize an additional point. This would be in opposition to the meter (see, above, n. 31). The corresponding conjunction $w$ - 'and' is often repeated at the beginning of each verse line or sentence in Neo-Aramaic and late East-Syriac poetry. Like its Neo-Aramaic equivalent, the Kurdish conjunction $\hat{u}$ is here consistently written as a non-syllabic, consonantal $w$ and treated accordingly for metrical purposes. 
çi derman nînin gelek pi êşin 35 هِ

û dilê min ŗ̧eş bû û gunehêd min boşin

û mirin nêzîk bû û ezî nexoşim

4. wehîdekim hebû spehî û layîq bû

destê wî dayim bi qelem girtî bû

İncîl û k'itêba dayim li k'oşê bû

paşê mirina wî babê yexsîr bû

5. ya mîrê mezin xolqetê tema

tu min ji bîr neka ez kolê tema

û gunahêd min bihêla ez 'ebdê tema

Xodê şola ta ${ }^{36}$ hemû k'erema

6. ezî feqîrim û qewî xerîbim

û ezî zelîlim û qewî yexsîrim

ya Xodê min xilas bika ezî bêhalim

ya rebb el'ezîm her t'opalim

7. rịj li min ava ${ }^{37}$ bû û dunîya tarî bû

feqîr bûm û xerîb 'emirê min xilas bû

ev dunîya betal ji min razî nebû

hêvîyê min Xodê her lalê te bû

8. xerîbim xerîbim û ezî bêkesim

dayim nexoşim û ezî wehîdim

û mirin her heqa Xodê şakirim

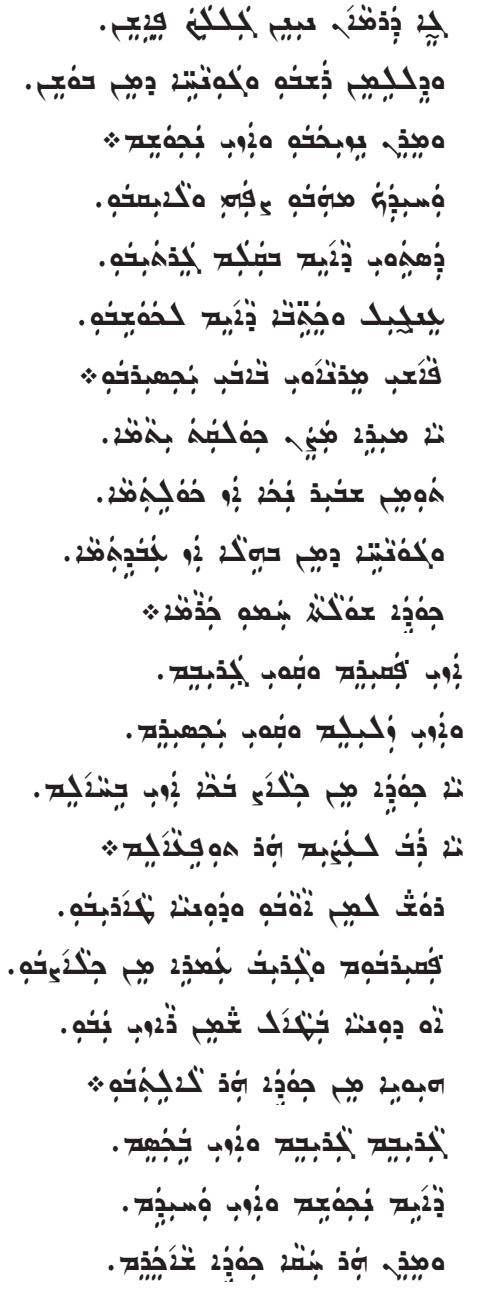

34 Since it does not seem to match birînêd, wittêşin should probably be read wê diêsin 'painful'. wê (also yêd) here is a plural and present continuous marker.

${ }^{35} \mathrm{P} i$ is the Badinānī variant of the preposition $b i$.

36 In common Badinānī şola te 'your work' (Arabic loanword šugl and the oblique case of $t u$ 'you (sg.)'. Arabic > Kurdish šulä is very common in Neo-Aramaic, meaning 'work, matter, thing'.

37 ava is a word which seems to occur basically in rojava 'west, occident' and -ava çun 'to set (sun)'. This might be a somewhat obsolete usage in the present context. 
gava ferman dikey 38 û ezî hazirim

9. hemû kes dibêjî mirin ye fera ${ }^{39}$

belê zorî nexoşa li hindeka dera

û qewî bêç'ara û zor bêy mefera

girîn û rûndikan şirînin û şekira

10. ezî yexsîr bûm li wê dunîyaya ${ }^{40}$

mirofêd min mirin keyfim nemaya

ez bi tenê mehîma li deştan û beŗîya

û dilê min bê xem bû bê ax û oxîya

11. tê fikirin ya ostan dermanî k'îya ${ }^{41}$

bo mirina însanî her tiştek nîya

p'êxamber ta'mkir mirin û enbîya

çakan û salihan û morselîn û awlîya

12. Xodê te'ala xulquet kirîna

da guhdarî wî bîn dunîya çunîna

û çu xirabî nekeyn em 'ebdêd wîna

da li ma nestîne wan heft xezîna

13. xoşîya biheştê qiyasî lê nîya

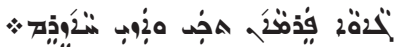

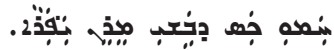

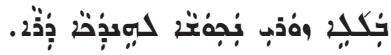

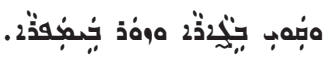

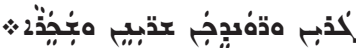

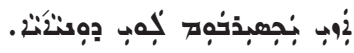

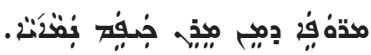

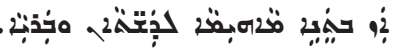

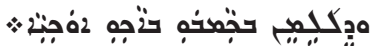

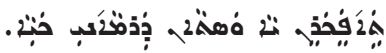

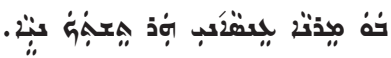

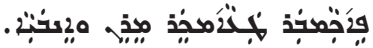

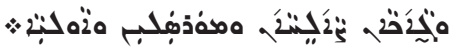

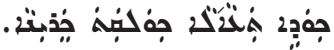

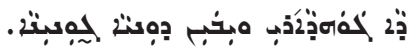

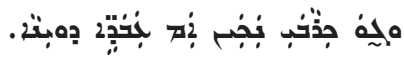

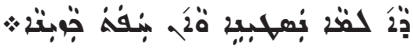

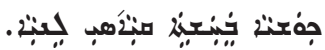

${ }^{38} \mathrm{It}$ is also possible, with a slight emendation, to read dikî, but the attested tkeay sounds very much like Badinānī dikay.

39 The attested yefera may be analyzed as formed by: (a) the demonstrative ye which however should be $y a$ in common Badinānī, since mirin 'death' is feminine. Within the present context, ye merely has a gender/number identification function; (b) the adjective fer 'inevitable'; (c) the copula $a$ 'is' which is commonly $e$ in Badinānī. In Badinānī, the phrase reads: mirin ya fer e, but I followed the Syriac script and the rhyme pattern of the verse. In some villages located to the northeast of Duhok, where many of the villagers were Jews and Christians, the copula $e$ is pronounced $a$ (personal communication of a native speaker).

40 The expected form is dunîyaê.

${ }^{41}$ Both the context and reading are puzzling. However, têfikerin could be tê $[d i+\hat{e}]$ fikirin 'to think about'. I guess kiya is k' $k$ 'îcannot be used with inanimate derman unless it is figuratively animated. 
bêhed layîqa û zorî cindîya

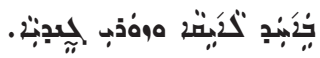

û kes qiyasî neket hindî spehîya

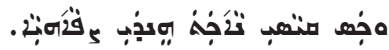
û avro nebêjin li ber çavan nîya?

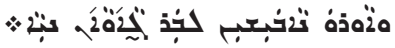

14. cehenem bêkara zorî nexoşa 'ezabek mezina bo ŗ̧uhêd r̦eşa qetlî û zenahan li dilê wan xoşa

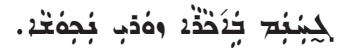

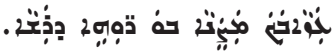

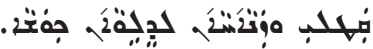
dê hingî pişman bin û şola wan boşa

15. çeka em bikeyn t'obe li gunaha?

da Xodê li ma bihêlî hemû qebaha zehmeta li hêlanê $\hat{e}^{42}$ ew wextê fetha li bo mirof geștêt3 bî li k'êşanê ŗuha

16. wextê derk'evî r̦uhê însanî hingî hazir dibî mêrikê şeytanî pisyar dêketin: bi kî tînê îmanîn? ciwabî zehmeta bo mirof nezanî

17. tirsek mezina dêjît li ber qazî qazî Xodêya bertîl nexwazî canê wî hingî hemû dêlerzî şer'ê wî dêket her bi surîn ${ }^{45}$ û tazî

18. eger saliha ŗ̧uhê însanî dêjît li biheştê li xoşiyêed dîwanî eger minafiqa peşkê şeytanî

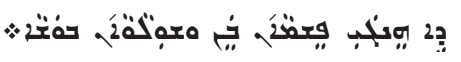

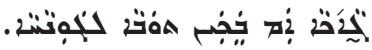

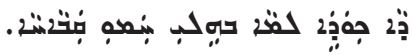

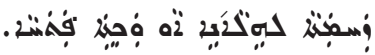

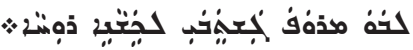

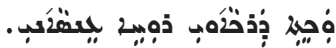

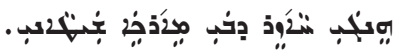

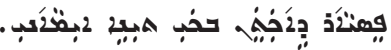

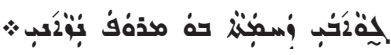

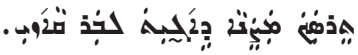

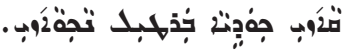

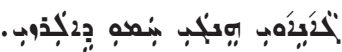

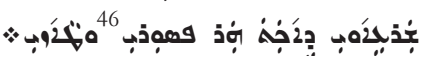

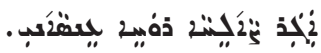

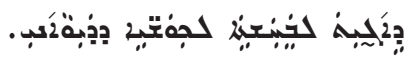

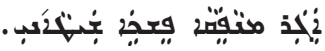

42 The reading lêhêlanê 'forgiveness' is also possible.

43 gest ' 1 . charity, 2. journey, trip' seems somewhat unlikely here. Alternatively, it could be read gehist bî̀ 'reach, have time'.

${ }^{4}$ In current Badinānī, line 16c would be: pisyar dê ketin: bi kê tînî [= ditîn îmanê [îman+feminine singular case marker $\hat{e}$ ?].

45 The manuscript has prusî̀ bi rusî ‘in Russian'. The probably erroneous shift $p$ surî $>$ prusî is easily explained as a metathesis and $p s u r \hat{\imath}$ 'in Syriac' fits the Christian symbolism and inspiration of the text better.

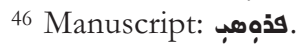


bi cehenem dêsojît bi k’ibrît û dermanî

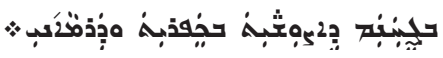

19. xilasî raborî̀ ${ }^{47}$ çi 'îlac nîna

hawar dêçekeyn hemû d sotîna ${ }^{48}$

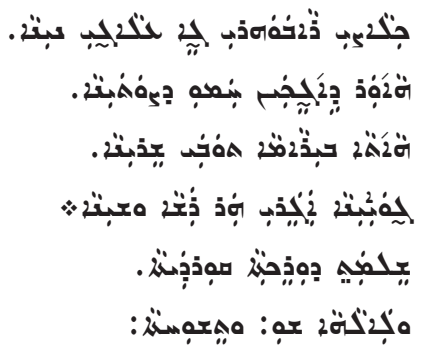

hata bîra me t'obe şirîna

çûina agirî her ŗ̧eşa û şîna

\section{TRANSLATION ${ }^{49}$}

[In the margin, in Classical Syriac:] A Kurdish Lament ${ }^{50}$

[Rubric, in Classical Syriac:] The following is a Kurdish poem composed by the Priest David of Barzane in Kanyafelhān. To [the tune of] "Full of confidence".

1. Lend your ears to this speech, ${ }^{51}$

a collection of sorrows and distress! ${ }^{52}$

The world is worthless and joyless.

Everything leaves one aghast. ${ }^{53}$

47 The $h$ in the attested rabohri may lead one to confuse it with rehber 'guide, leader'. In fact, it is raborî' the past' as a noun or 'passed' as a verb.

48 dêgekeyn consists of dêe (future marker), çe/ çi 'what', and the Badinānī present form of kirin 'to do'. $d$ in dșotina is the short form of gender/number marker yêd, prefixed to the past participle of sotîn 'to burn'. $n a$ (-ne in most Badinānī areas) is the first person plural of the verb 'to be'.

49 The translation is intended as an attempt to accept the text as it is. When a more idiomatic translation is proposed, the literal worktranslation is specified in the foot-notes.

${ }^{50}$ Lit. 'A sad/distressing poem in Kurdish'.

51 An alternative translation of this opening sentence is: "obey this speech!". If nothing is missing from the text, the use of -lêe guh dan 'to obey' would also be possible syntactically.

${ }^{52}$ Lit. 'A box/set [from qav 'box'?] of / strong [from qaw ? ] sorrow and unhealthiness'.

${ }^{53}$ Lit. 'One is astonished at every topic'. 
2. The death of an only son is bad and bitter.

It is heart-rending ${ }^{54}$ for mother and father.

Those who see nothing of it do not know what is like.

Do not blame me, oh friends and companions!

3. My wounds are sore, they are most painful. ${ }^{5}$

They are incurable, excruciating.

My heart became dark and my sins multiple.

Death approached me and I am sick.

4. I had an only son, he was handsome and well-mannered.

His hand constantly gripped the pen,

Gospels and Scriptures were always on his lap.

After he died, his father became a prisoner.

5. O Grand Emir, I am Your creature.

Do not forget me! I am Your slave.

Take away my sins! I am Your servant.

O God, Your deeds are favorable.

6. I am poor and a complete stranger.

I am abject and deeply imprisoned.

Release me, oh God! I am exhausted.

Oh Supreme Lord, I am lamed. ${ }^{56}$

7. The day passed to sunset and the world grew dark to me.

I was poor and a stranger, my life was over. rivation'.

${ }^{54}$ Lit. 'A box [from qav 'box'?] / strong [from qawt?] sorrow and dep-

55 If we read <kollen $>$ as kullen 'completely', another translation will be possible: "my wounds all-in-all are very painful". In Iraqi Christian Neo-Aramaic manuscripts, kŏo 'all, each', deriving from Aramaic *kŭll, is often written with rwähäa, i.e. /o/.

56 topalim 'I am lamed'? A better reading might be: $t$ opê 'alim '[oh] all the mob of the world!' Most of the meanings encountered in the various usages of $t>p$ 'mob, gathering, crowd, cannon' may be appropriate here, and their juxtaposition can help to determine the meaning used by David of Barazne. It seems, however, to occur with a somewhat mystic intention, where it may have the sense of 'entirety, whole of the creature' as a sign of God. 
I did not find favor with this futile world.

My hope, oh God, was in You.

8. I am a stranger, I am a stranger and I have no kindred, I am always sick and alone.

Death is a law, oh God, I am thankful and I am ready to die when You command me

9. Everyone says death is inevitable Yes! It is very bad in so many ways. ${ }^{57}$ There is no help or escape from it. Weeping and tears are sweet as ${ }^{58}$ sugar.

10. I became a prisoner in this world My relatives died. I lost all enjoyment. I was left alone in the plains and the desert and then my heart was freed of cares, without aches and pains. ${ }^{59}$

11. Oh Lord, think, who can resist it! 60 For the death of a human being, there is no remedy. Prophets tasted death, ${ }^{61}$ and so did the good and righteous people, apostles and saints.

12. The Most High God, the Creator, you should listen to Him. The world is like that.

57 The meaning of the second part of the line (li bindeka dera) is doubtful.

${ }^{58}$ Lit. 'and'.

${ }^{59}$ Lit. 'without ah and without ouch'.

60 The meaning of this line is somewhat doubtful, and the translation suggested is tentative.

${ }^{61}$ The Biblical (Hebrew 2:9 in the East-Syriac manuscript tradition of the Peshitta: "for he, apart from God, for the sake of everyone tasted death") and Qur'ānic expression (XXI, 35: "everyone shall taste death") also occurs in Neo-Aramaic and is used in contexts meaning "all men die". A. Mengozzi, Religious Poetry in Vernacular Syriac from Northern Iraq (17th-20th Centuries). An Anthology, CSCO 628, Scriptores Syri 241 (Leuven: Peeters, 2011), 99 and 106. For West- and East-Syriac readings of Hebrews 2:9, see S. P. Brock, "Hebrew 2:9a in Syriac tradition," Novum Testamentum 27 (1983), 236-44. 
Do not do wicked deeds! We are His servants.

He should not take away from us those seven treasures ${ }^{62}$.

13. There is no limit to the happiness of Paradise.

It is boundlessly right and splendid.

No one can say how splendid it is

and do they say that day is unimaginable?

14. Hell does no good. It is very unpleasant.

In it there will be great torment for sinful ${ }^{63}$ souls.

For their heart delights in killing and adultery, then they will regret it and their regrets will be many.

15. What shall we do to repent of our sins?

Let us, oh God, remove all our hideousness

and our trouble at the time of departure! That time of victory

will be a journey to transport the soul for human beings.

16. When a human soul leaves the body, then the shade of the Devil comes.

He will ask: "In whom do you believe?"

For a human being, it is hard to reply. He does not know.

17. There is a great fear before the judge

The judge is God. He does not want bribes.

At that time his whole spirit trembles

His sentence will strike in Syriac ${ }^{64}$ and Arabic.

18. If a man's soul is righteous,

he will live in Paradise with the joys of the heavenly hosts.

If it is hypocritical with a devilish spark, he will burn in Hell like lighted fat.

19. No cure will deliver us from the past

Cry for help! What shall we do? All shall be burned.

We remember that repentance is sweet, death by fire is always black and mournful.
62 Sacraments?
63 Lit. 'black'.
${ }^{64}$ Bi rusî 'in Russian' in the manuscript. See n. 45, above. 
[Rubric, in Classical Syriac:] The end of the Kurdish poem. To God be glory and praise!

\section{BIBLIOGRAPHY}

Bausani, A. "Le lingue islamiche. Interazioni e acculturazioni." In Il mondo islamico tra interazione e acculturazione, ed. A. Bausani and B. Scarcia Amoretti. Roma: Istituto di studi islamici, 1981.

Bausani, A. "Letteratura neopersiana." In Storia della letteratura persiana, ed. A. Pagliaro and A. Bausani. Milano: Nuova Accademia, 1960.

Borbone, P. G. "Syroturcica 1: The Önggüds and the Syriac Language." In Malphono w-Rabo d-Malphone. Studies in Honor of Sebastian P. Brock, Gorgias Eastern Christian Studies 3, ed. G. A. Kiraz. Piscataway, NJ: Gorgias, 2008.

Borbone, P. G. "Syroturcica 2: The Priest Särgis in the White Pagoda." Monumenta Serica. Journal of Oriental Studies 56 (2008): 487-503.

Borbone, P. G. 'Syroturcica 3: Hulegu's rock-climbers. A shortlived Turkic word in 13th-14th century Syriac historical writing." In Studies in Turkic philology. Festschrift in honour of the 80th birthday of Professor Geng Shimin. Beijing: Minzu Dashue Chubanshe, 2009.

Braida, E. "Garshuni Manuscripts and Garshuni Notes in Syriac Manuscripts." Parole de l'Orient 37 (2012): 181-98.

Briquel Chatonnet, F. "De l'intérêt de l'étude du garshouni et des manuscrits écrits selon ce système." In L'Orient chrétien dans l'empire musulman. Hommage au Professeur Gérard Troupeau, Studia arabica 3, ed. G. Gobillot and M.T. Urvoy. Paris: Éditions de Paris, 2005.

Brock, S. P. "Hebrew 2:9a in Syriac tradition." Novum Testamentum 27 (1983): 236-44.

Chyet, M. L. "Neo-Aramaic and Kurdish: An Interdisciplinary Consideration of their Influence on Each Other." Israel Oriental Studies 15 (1995): 219-49.

Chyet, M. L. "Kurmanji Kurdish Lexicography: A Survey and Discussion.” Web site of the Kurdish Academy of Language, 1997 
[www.kurdishacademy.org/?q=fa/node/142; last visit November 2013]

Dehqan, M. "A Kirmașanî Translation of the Gospel of John." Journal of Eastern Christian Studies 61:1\&2 (2009): 207-11.

Fiey, J. M. Assyrie Chrétienne. Vol. I. Beirut: Imprimerie catholique, 1965.

Fuad, K. Kurdische Handschriften, Verzeichnis der orientalischen Handschriften in Deutschland 30. Wiesbaden: F. Steiner, 1970.

Habbī, Y. "Mahțūtāāt abrašiyyat "Aqrā." In Fahāris al-mabtūtutat alsuryāniyya fí l-Irāq. Baghdad: Al-Mağmae al- ilmī al- irāqī, 1981 [in Arabic].

Harrak, A. Catalogue of Syriac and Garshuni Manuscripts. Manuscripts Owned by the Iraqi Department of Antiquities and Heritage, CSCO 639, Subsidia 126. Leuven: Peeters, 2011.

Kapeliuk, O. "Language Contact between Aramaic Dialects and Iranian." In The Semitic Languages. An International Handbook, HSK 36, ed S. Weninger. Berlin: de Gruyter, 2011.

Kapeliuk, O. "A Contrastive Analysis of Tenses in Urmi NeoAramaic and in Kurdish." In Beiträge zur semitischen Dialektologie. Festschrift für Werner Arnold zum 60. Geburtstag, ed. R. Kuty, U. Seeger and Sh. Talay. Wiesbaden: Harrassowitz, 2013. 161-70

Kessel, G. "The importance of the manuscript tradition of the 'Book of Grace' for the study of Garšunīi." Parole de l'Orient 37 (2012): 215.

Kiraz, G. A. Türrās Mamllā. A Grammar of the Syriac Language, vol. 1 Orthography. Piscataway, NJ: Gorgias Press, 2012.

Kreyenbroek, P. G. "The Lawij of Mor Basilios Shim un: A Kurdish Christian Text in Syriac Script.' Journal of Kurdish Studies 1 (1995): 29-35.

MacKenzie, D.N. Kurdish Dialect Studies I, London Oriental Series vol. 9. Oxford: Oxford University Press, 1961.

Maggi, M. and P. Orsatti. "Two Syro-Persian Hymns for Palm Sunday and Maundy Thursday." In The Persian Language in History, ed. M. Maggi and P. Orsatti. Wiesbaden: Harrassowitz, 2011. 
Marazzi, U. "Sull'importanza dei testi osmanli in caratteri siriaci." In Studia Turcologica memoriae Alexii Bombaci dicata, ed. A. Gallotta and U. Marazzi. Napoli: Istituto universitario orientale, 1982.

Mengozzi, A. A Story in a Truthful Language. Religious Poetry in Vernacular Syriac from (North Iraq, 17th century). CSCO 589-90, Scriptores Syri 230-1. Leuven: Peeters, 2002.

Mengozzi, A. "The History of Garshuni as a Writing System: Evidence from the Rabbula Codex." In CAMSEMUD 2007. Proceedings of the 13th Italian Meeting of Afro-Asiatic Linguistics, held in Udine, May 21st-24th, 2007, ed. F. M. Fales and G. F. Grassi. Padova: S.A.R.G.O.N. Editrice e Libreria, 2010.

Mengozzi, A. Religious Poetry in Vernacular Syriac from Northern Iraq (17th-20th Centuries). An Anthology, CSCO 627-8, Scriptores Syri 240-1. Leuven: Peeters, 2011.

Mengozzi, A. "Persische Lyrik in syrischem Gewand.Vierzeiler aus dem Buch des Khamis bar Qardahe (Ende 13. Jahrhundert)." In the proceedings of the Syrologentag (Göttingen, 16.-17. Dezember, 2011). Forthcoming.

Mengozzi, A. "The Book of Khamis bar Qardahe: History of the Text, Genres and Research Perspectives." In Syriac Encounters, proceedings of the Sixth North American Syriac Symposium (Duke University, Durham, North Carolina, June 26-29, 2011). Forthcoming.

Murre-van den Berg, H.L. "Classical Syriac, Neo-Aramaic, and Arabic in the Church of the East and the Chaldean Church between 1500 and 1800." In Aramaic in its Historical and Linguistic Setting, Akademie der Wissenschaften und der Literatur, Mainz: Veröffentlichungen der Orientalischen Kommission 50, ed. H. Gzella and M. L. Folmer. Wiesbaden: Harrassowitz, 2008.

Pennacchietti, F. A. "Un manoscritto curdo in karshuni da Aradin (Iraq)." Annali dell'Istituto Universitario Orientale di Napoli 36 (1976): 548-52.

Poizat, B. Jacques Rhétoré. La versification en soureth (araméen contemporain), CSCO 647, Subsidia 131. Leuven: Peeters, 2013.

Proverbio, D. V. “Turco-Syriaca. Un caso estremo di sincretismo linguistico e religioso: i libri di Tommaso Șarrāf da Edessa (XVIII sec.) nella biblioteca portativa di Tommaso Caldeo da 
Alqôš." Miscellanea Bibliothecae Apostolicae Vaticanae 11 (2004): 583-635.

Prym E. and A. Socin, Kurdische Sammlungen. Erzäblungen und Lieder in den Dialekten des Tûr 'Abdin und von Bobtan, a. Die Texte. St. Petersburg: Commissionaires de l'Académie Impériale des sciences, 1890.

Sabar, Y. The Folk Literature of the Kurdistani Jews: An Anthology, Yale Judaica Series 23. New Haven, CT: Yale University Press, 1982.

Sabar, Y. A Jewish Neo-Aramaic Dictionary. Semitica Viva 28. Wiesbaden: Harrassowitz, 2002.

Sachau, E. Verzeichnis der syrischen Handschriften der Königlichen Bibliothek zu Berlin. B. 1. Berlin: Asher, 1899.

Sims-Williams, N. "Early New Persian in Syriac script: Two texts from Turfan." Bulletin of SOAS 74:3 (2011): 353-74.

Sony, B. Le catalogue des manuscrits du couvent des Dominicains de Mossoul. Mosul, 1997 [in Arabic].

Teule, G. B. "The Syriac Renaissance." In The Syriac Renaissance, Eastern Christian Studies 9, ed. G. B. Teule and C. Fotescu Tauwinkl. Leuven: Peeters, 2010.

Thackston, W. M. Kurmanji Kurdish. A Reference Grammar with Selected Readings. 2006 [www.fas.harvard.edu/ iranian/Kurmanji/kur manji_1_grammar.pdf; last visit November 2013]

Wilmshurst, D. The Ecclesiastical Organisation of the Church of the East, 1318-1913, CSCO 582, Subsidia 104. Leuven: Peeters, 2000.

Younansardaroud, H. "Die türkischen Texte aus dem Buch 'Manuel de Piété' von Paul Bedjan (1893)." In Studia Semitica et Semitohamitica. Festschrift für Rainer Voigt anläßlich seines 60. Geburtstages am 17. Januar 2004, Alter Orient und Altes Testament 317, ed. B. Burtes, J. Tropper and H. Younansardaroud. Münster: Ugarit, 2005. 
